\title{
The Effectiveness of Blood Loss Measuring Mattress in Maternity
}

\author{
Elsa Noftalina ${ }^{1}$, Intan Purnamasari ${ }^{2}$, Firdha Kusuma Wulandari ${ }^{3}$, \\ Wina Widyanti ${ }^{4}$ \\ ${ }^{1,2,3,4}$ Polytechnic of 'Aisyiyah Pontianak, Indonesia \\ Corresponding Author: Elsa Noftalina
}

\begin{abstract}
Background: Maternal mortality rate (MMR) is an important indicator that describes the health status and welfare of the people in a nation. WHO estimates MMR in the world every day is at 817 people. Maternal mortality is mostly caused by complications during pregnancy, childbirth, and postpartum where these complications are direct obstetric complications. Postpartum hemorrhage is the main cause of maternal death. Factors causing postpartum hemorrhage are uterine atony, retained placenta, laceration of the birth canal, and blood disorders. The delay in diagnosis and treatment of postpartum hemorrhage is mostly caused by the estimated volume of blood loss in labor that is too low and the lack of equipment or clinical skills to solve the problem. Errors in calculating the volume of bleeding lost during delivery are too late to recognize bleeding that can lead to death due to lack of skills to prevent and treat postpartum hemorrhage. Research objective is to determine the effectiveness of the product (mattress) in measuring blood loss in maternity.

Research Method: The type of research used was experimental research, namely one shot case study. The study was conducted in two Independent Midwife Practices located in the city of Pontianak, West Kalimantan, Indonesia from May to September 2021. The subjects of the study were maternity mothers and birth attendant midwives with a consecutive sampling technique of 30 samples divided into 3 groups with 10 samples respectively of each product. The instrument used to collect data was a questionnaire with a Likert scale which was distributed to maternity mothers as direct users of the mattress and midwives who helped use
\end{abstract}

the mattress. Statistical analysis used was one way ANOVA test.

Research results based on the one way ANOVA test, it was found that the average assessment given by patients and midwives on the three mattress models had a significant difference with a $\mathrm{p}$ value of 0.000 . In the Post Hoc Turkey HSD test, it was found that there was no difference in the mean of patient assessments between model 1 and model 2 with $\mathrm{p}$ value $=$ 0.239 . The case was different between model 1 and model 3 and model 2 and model 3, namely, there was a significant difference. Model 1 and model 3 have a $p$ value $=0.009$ with an average difference of 2,700 while model 2 and model 3 have a $\mathrm{p}$ value $=0.000$ with an average difference of 4,100. In the Post Hoc Turkey HSD test, there was a significant difference in the average of the midwives' assessments on the three mattress models. Model 1 and model 2 have a $\mathrm{p}$ value $=0.000$ with an average difference of 5,800, model 1 and model 3 have a $\mathrm{p}$ value $=0.000$ with an average difference of 6,900 , while model 2 and model 3 have a $p$ value $=0.000$ with an average difference of 12,700 .

Keywords: Maternity bleeding, Measuring mattress

\section{INTRODUCTION}

Maternal mortality rate (MMR) is one of the important indicators that describes the health status and welfare of the people in a nation. According to the latest data from the World Health Organization (WHO), the maternal mortality rate in the world in 2017 was 817 people every day. WHO estimates that the 
maternal mortality rate (MMR) in the world is 211 per 100,000 live births (1). The maternal mortality rate (MMR) in Indonesia, according to the Census Rate Survey (Supas) in 2015, was 305 per 100,000 live births. In 2018, West Kalimantan Province had a maternal mortality rate (MMR) of 95 per 100,000 live births with the highest number of maternal deaths was in Kubu Raya district, which was 158 per 100,000 live births, while the MMR in Pontianak was 50 per 100,000 live births(2).

Maternal mortality (MMR) is caused by multiple factors. Postpartum hemorrhage is the main cause of maternal death in developing countries like Indonesia (3). Postpartum hemorrhage is defined as blood loss of more than $500 \mathrm{cc}$ that occurs after the baby is born vaginally and more than $1000 \mathrm{cc}$ after abdominal delivery (Sectio Caesaria)(4). Factors causing postpartum hemorrhage include uterine atony, retained placenta, laceration of the birth canal, and blood disorders. Agency of Health Research and Development (Balitbangkes) in 2016 showed data on the causes of maternal death from obstetric hemorrhage of $27.03 \%$ (5). Based on the WHO analysis, $27.1 \%$ of the causes of maternal death were bleeding, more than $2 / 3$ of them were postpartum hemorrhage (PPH) (6). A study conducted by Achadi (2019) stated that the highest maternal mortality in 2015-2017 was caused by obstetric bleeding in the first 24 hours after delivery, which was $38.3 \%$ (7).

The delay in diagnosis and treatment of postpartum hemorrhage is mostly caused by the estimated volume of blood loss in childbirth that is too low and the lack of equipment or clinical skills to solve the problem. At present, the calculation of the estimated volume of bleeding lost during delivery is the method of visual estimation, direct measurement, gravimetic, photometric, changes in hematocrit and hemoglobin and several other methods (8). The ability to identify and respond to the amount of postpartum blood loss can reduce the incidence of postpartum hemorrhage which will be associated with maternal morbidity and mortality. Errors in calculating the volume of bleeding lost during delivery are too late to recognize bleeding that can lead to death due to lack of skills to prevent and treat postpartum hemorrhage. Based on the above background, the researchers made an innovative product that can provide benefits for calculating the volume of blood loss during childbirth. This innovation is the development of a tool with direct measurement. A tool that resembles a mattress that can be used as a base during childbirth is then modified with the addition of a bag (modified urine bag) to accommodate and measure the volume of blood loss. This tool is expected to provide a solution for birth attendants, especially midwives, in recognizing bleeding that occurs in maternity mothers so that there are no delays and errors in calculating the amount of blood lost during delivery. Researchers have made three product designs, each of which has been validated by health and midwifery physicists, which were then made according to the design revisions and tested on research samples. The purpose of this study was to determine the effectiveness of the product (mattress) in measuring maternal blood loss.

\section{LITERATURE REVIEW Maternal Mortality Rate (MMR)}

Maternal mortality rate (MMR) according to WHO is the number of deaths during pregnancy or within a period of 42 days after termination of pregnancy, due to all causes related to or aggravated by pregnancy or its management, but not caused by accidents or injuries. MMR is one indicator in determining the degree of public health. Indonesia has the highest MMR compared to ASEAN countries. The maternal mortality rate in Indonesia according to the 2015 Census Rate Survey (Supas) is 305 per 100,000 live births. The global target of SDG's (Sustainable Developmental Goals) is to reduce maternal mortality by 70 per 100,000 live births in 
2030. Referring to current conditions, the potential to achieve the SDG's target to reduce MMR is off track, meaning that hard and serious work is needed to reach it (9).

Maternal mortality and maternal morbidity have long been a health problem. Around $25-50 \%$ of deaths of women of childbearing age are caused by things related to pregnancy and childbirth (10). The cause of the majority of cases of maternal death can actually be prevented, and it is estimated that more than $40 \%$ of pregnant women have a risk of obstetric abnormalities that are not too fatal and about $15 \%$ of births are complicated by a fatal condition requiring emergency care (11). The main complications that account for $80 \%$ of all maternal deaths are severe bleeding (mostly postpartum bleeding), infection (usually after delivery), preeclampsia/eclampsia, and unsafe abortion(4).

\section{Post Partum}

Postpartum hemorrhage is bleeding or blood loss of $500 \mathrm{cc}$ or more that occurs after the child is born. Bleeding can occur before, during, or after the delivery of the placenta. The types of postpartum hemorrhage are as follows:(12)

Primary bleeding; Bleeding that includes all bleeding events within 24 hours after delivery. The most common causes are uterine atony, genital trauma (including spontaneous causes and trauma due to management or delivery disorders), disseminated intravascular coagulation and uterine inversion.

Secondary bleeding; Bleeding that includes all primary postpartum hemorrhage events and that occurs between 24 hours after the birth of the baby and 6 weeks postpartum. The causes are retained placental fragments or amniotic membranes, the release of dead tissue after delivery is blocked (can occur in the cervix, vagina, bladder and rectum), open wounds to the uterus

\section{Methods or Measuring Instruments for Estimating Blood Loss}

There are several methods or techniques that can be used to calculate the estimated amount of blood loss after childbirth:

\section{Visual Estimation}

Visual estimation is the most frequently used method in daily practice to measure blood loss in childbirth in the United States. This method is still used even though some researchers have shown that this method is less accurate. Some have found that this method predicts more or less blood loss than the actual blood loss, but not a few studies show that visual estimation predicts blood loss close to the true blood loss value(13)

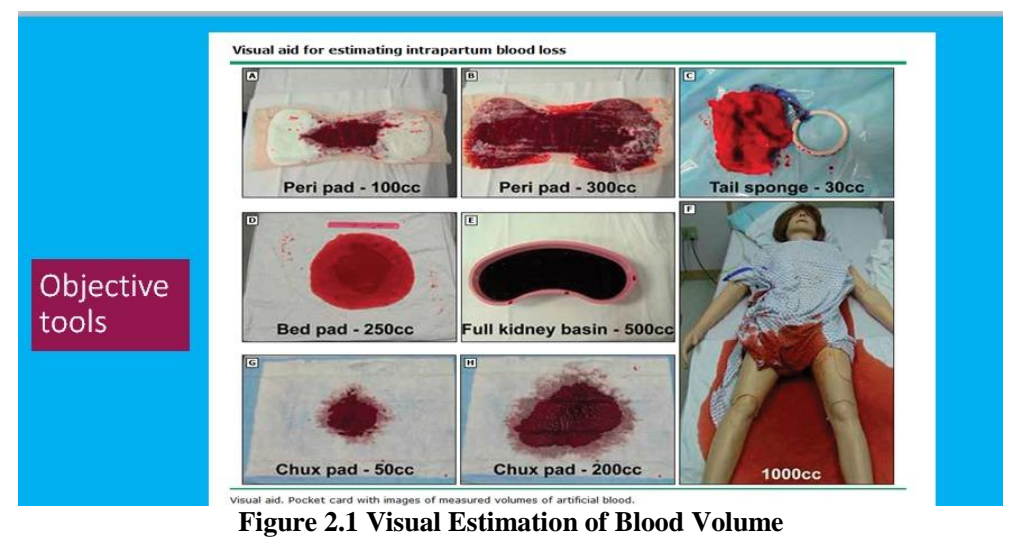

\section{Direct measurement}

This method uses a tool to collect blood directly and is used during childbirth to accurately measure blood loss. A study in 1898 and 1904 carried out direct measurement methods, one of which was by 
placing a basin or container in front of the external genitalia to collect blood and the other by using a copper funnel that passed through the bed mattress at buttocks height which later the blood would flow in a reservoir under the bed. The most often used is a tarpaulin with a pouch at the end (drapes) which will collect the blood in the tarpaulin at the end of the bag and measurements can be made. One drawback that is difficult to avoid is when blood is mixed with other fluids such as urine and amniotic fluid. In addition, this method cannot collect all the blood to be counted, for example, which is attached to gloves, aprons, linens and which is attached to the mother's buttocks and back(8).

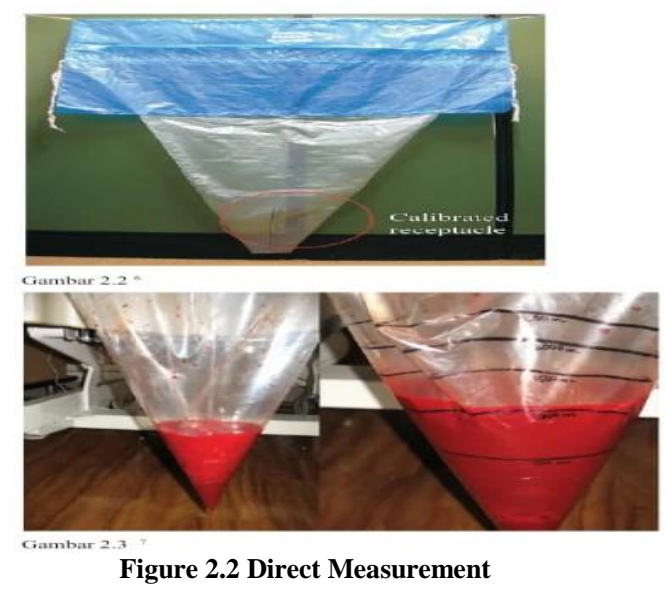

\section{Gravimetric}

The gravimetric method is carried out by measuring the weight of the material used such as a sponge and subtracting the previous weight to estimate the amount of blood lost. This method is used primarily to assess blood loss in surgery (14). Five publications have used the gravimetric method and all of these studies were used to calculate intraoperative blood loss, one of which used a computer to calculate the contents of the suction tube and sponge used. Then the patient's height and weight are entered into the computer, the computer will automatically calculate the acceptable blood loss, which is $10 \%$ of the total blood volume. The computer will notify when the amount of blood loss is more than $10 \%$.
This method can calculate the amount of blood loss that is large or very small. In another study comparing the prediction of blood loss with the gravimetric method and laboratory tests, significant results were obtained in calculating blood loss, supporting the use of the gravimetric method because it is faster and cheaper than laboratory tests, but this method does not distinguish other fluids found in materials such as amniotic fluid and urine(15).

\section{Photometry}

One of the photometric techniques is used to convert the blood pigment to alkaline hematin. This alkaline hematin method is used as the gold standard for blood counting. All gauze, dressings, towels containing blood are collected in plastic bags and sent to the laboratory and then washed with ammonium hydroxide water and surface active agent to accelerate the release of hemoglobin. The sample from the solution is centrifuged and filtered, then the oxyhemoglobin level is measured with a photoelectric colorimeter and compared with the hemoglobin level before delivery $(8)$

\section{Changes in hematocrit and hemoglobin Changes in hematocrit and} hemoglobin before and after delivery can be used to calculate the amount of blood loss after delivery. The American College of obstetricians and gynecologists states that the hematocrit decreases by as much as $10 \%$ after delivery. Assessment of hematocritrutin can be done if facilities are available, however, postnatal hematocrit measurement is not necessary in clinically stable women with estimated blood loss of less than $500 \mathrm{ml}(16)$

\section{MATERIALS \& METHODS}

The research type used was experimental research, namely one shot case study where researchers observed the results of a group that got treatment. This study used three mattress products that have been designed for mothers to give birth, then 
under or beside the mattress, a bag measuring the blood was placed that came out during childbirth. The study was conducted in two Independent Midwife Practices located in the city of Pontianak, West Kalimantan, Indonesia from May to September 2021. The subjects of the study were maternity mothers and birth attendant midwives with a consecutive sampling technique of 30 samples divided into 3 groups with 10 each. Samples of each product. The instrument used to collect data was a questionnaire with a Likert scale which was distributed to maternity mothers as direct users of the mattress and midwives who helped use the mattress. The researcher did not provide inclusion criteria in the use of the mattress because the purpose of making the mattress so that it can be used by maternity mothers in any condition so that the amount of blood loss can be immediately assessed and become a diagnosis in the delivery process and the patient can be treated immediately in the event of postpartum hemorrhage. As for analyzing the data collected from the results of the questionnaire, the formula for the percentage of product feasibility values was used. The conclusion of the qualification of the percentage obtained was converted to the level of achievement and qualification. Then statistical analysis used was one way ANOVA test to find out which products were more effective for pregnant women and midwives.

\section{RESULT}

Product trials were carried out by using 10 samples on each product to see the effectiveness of the products that had been made. The effectiveness of the product was assessed based on a questionnaire given to midwives and patients. To analyze the data collected from the results of the questionnaire, the formula for the percentage of feasibility value was used (17). The qualification conclusion from the percentage obtained was converted to the level of achievement and qualification. Product trials were carried out in two PMBs who collaborated in this research. The results of the product trials carried out are as follows:

Table 1 Percentage of Product Feasibility

\begin{tabular}{|l|l|}
\hline Mattress Model & Percentage of feasibility effectiveness \\
\hline Model 1 & $69,92 \%$ \\
\hline Model 2 & $83,7 \%$ \\
\hline Model 3 & $51,3 \%$ \\
\hline
\end{tabular}

Then, to assess the effectiveness between the mats, statistical analysis was carried out by using one way ANOVA. Before the one way annova statistical analysis was carried out, the data was tested for normality first. This study used the Kolmogorov Smirnov normality test. The research data was primary data that came from the results of the patient assessment questionnaire (childbirth mothers) who used the mattress and the midwife who assessed how the mattress worked. The results of the normality test stated that the assessment data from maternity mothers and midwives were normally distributed with a significance value of 0.250 and 0.749 respectively, so to assess the effectiveness of the mattress, one way ANOVA analysis can be used. To determine the data variance, a test of homogeneity of variance was used and the results showed that the existing data did not vary (homogeneous data) which was indicated by a $\mathrm{p}$ value $>0.05$ (Table 2 ).

Table 2 Homogeneity

\begin{tabular}{|l|l|l|l|l|}
\hline \multicolumn{2}{|c|}{ Test of Homogeneity of Variances } \\
\hline & Levene Statistic & df1 & df2 & p value \\
\hline Patient Assessment & 1.507 & 2 & 27 & 0.240 \\
\hline Midwife Assessment & 0.826 & 2 & 27 & 0.448 \\
\hline
\end{tabular}

Table 3 ANOVA Test Results

\begin{tabular}{|l|l|l|l|l|}
\hline & Mean & \multirow{2}{*}{ p value } \\
\cline { 2 - 4 } & Model 1 & Model 2 & Model 3 & \\
\hline Patient Assessment & 16,80 & 18,20 & 14,10 & 0,000 \\
\hline Midwife Assessment & 27,70 & 33,50 & 20,80 & 0,000 \\
\hline
\end{tabular}


Elsa Noftalina et.al. The effectiveness of blood loss measuring mattress in maternity.

Table 4 Results of Post Hoc Tukey HSD
\begin{tabular}{|l|l|l|l|l|}
\hline \multirow{3}{*}{ Patient Assessment } & \multirow{2}{*}{ model 1 } & Mattress Model & Mean Difference & p value \\
\cline { 3 - 5 } & & Model 2 & -1.400 & 0.239 \\
\cline { 2 - 5 } & \multirow{2}{*}{ Model 2 } & model 1 & 2.700 & 0.400 \\
\cline { 3 - 5 } & & Model 3 & 4.100 & 0.239 \\
\cline { 2 - 5 } & \multirow{2}{*}{ Model 3 } & model 1 & -2.700 & 0.000 \\
\cline { 3 - 5 } & & Model 2 & -4.100 & 0.009 \\
\hline Midwife Assessment & \multirow{2}{*}{ model 1 } & Model 2 & -5.800 & 0.000 \\
\cline { 3 - 5 } & & Model 3 & 6.900 & 0.000 \\
\cline { 2 - 5 } & \multirow{2}{*}{ Model 2 } & model 1 & 5.800 & 0.000 \\
\cline { 3 - 5 } & & Model 3 & 12.700 & 0.000 \\
\cline { 2 - 5 } & \multirow{2}{*}{ Model 3 } & model 1 & -6.900 & 0.000 \\
\cline { 3 - 5 } & & Model 2 & -12.700 & 0.000 \\
\hline
\end{tabular}

Table 5. Effectiveness of Tukey HSD Test
\begin{tabular}{|l|l|l|l|l|}
\hline \multirow{3}{*}{ Patient Assessment } & Mattress Model & \multicolumn{3}{|c|}{ Subset for alpha $\mathbf{0 , 0 5}$} \\
\cline { 2 - 5 } & & $\mathbf{1}$ & $\mathbf{2}$ & $\mathbf{3}$ \\
\cline { 2 - 6 } & Model 3 & 14.10 & & \\
\cline { 2 - 6 } & Model 1 & & 16.80 & \\
\cline { 2 - 6 } & $p$ value 2 & 1.000 & 0.239 & \\
\hline Midwife Assessment & Model 3 & 20.80 & & \\
\cline { 2 - 6 } & Model 1 & & 27.70 & \\
\cline { 2 - 6 } & Model 2 & & & 33.50 \\
\cline { 2 - 6 } & $p$ value & 1.000 & 1.000 & 1.000 \\
\hline
\end{tabular}

\section{DISCUSSION}

\section{Model 1}

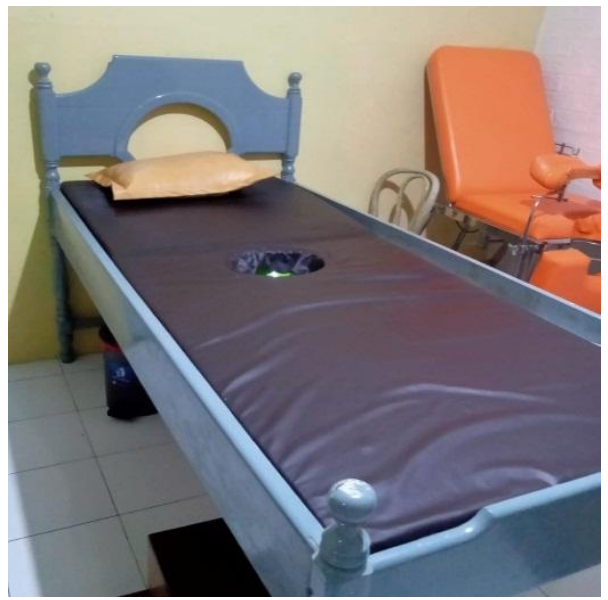

Model 1 Front View

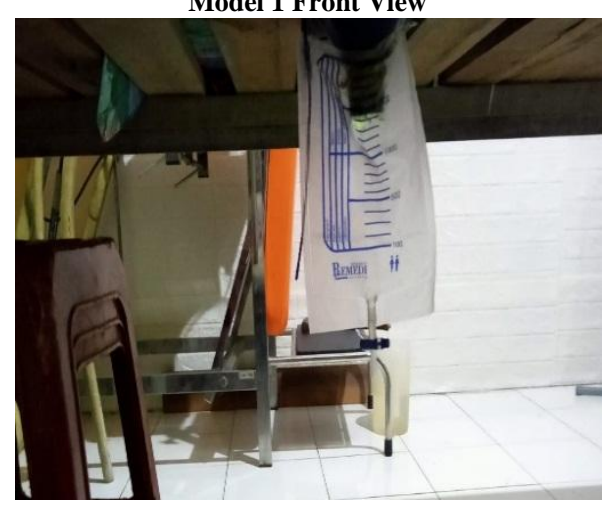

Blood bag that has not been filled with blood

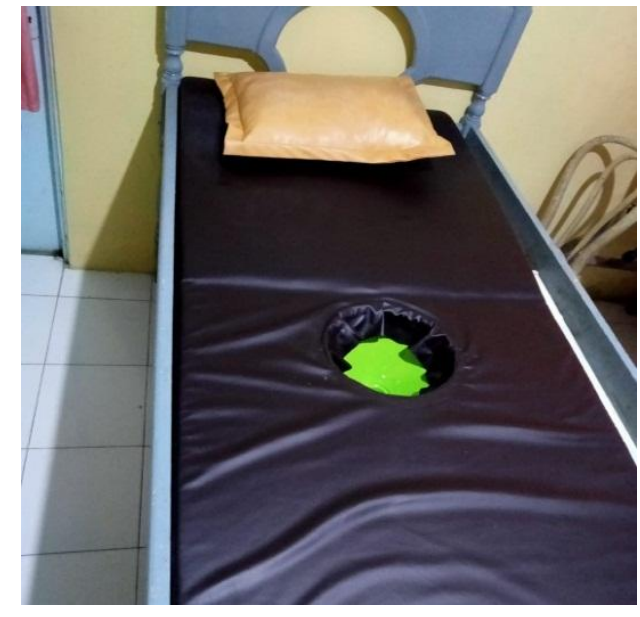

Model 1 Top View

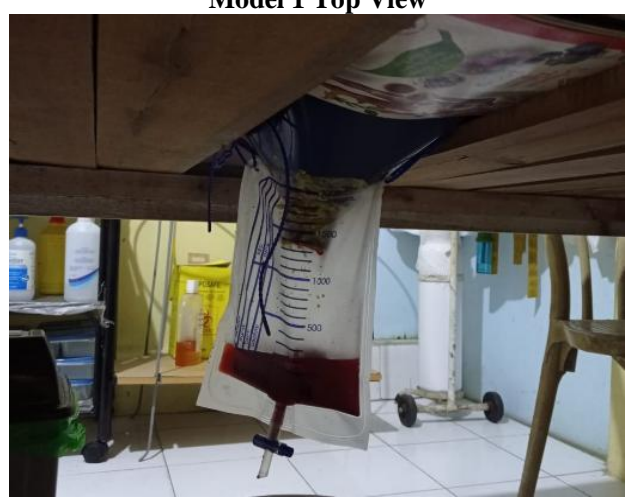

Blood bag that has been filled with blood Figure 1. Mattress Product Model 1

Based on the results of trials given to midwives and patients, it can be conducted and supported by questionnaires concluded that model 1 has an effectiveness 
percentage of $69.92 \%$ in which its qualification results are "good" and the decision is "appropriate and does not need to be revised". However, one of the results from the midwife assessment $\mathrm{s}$ ttated hat the hole in the middle of the mattress was too high up so it was not right on the patient buttocks, this is because the patient height exceeds the average height of Asian people. Then, another obstacle, with these conditions, it also makes it difficult for midwives to suture birth canal wounds on patients. While the blood bag in the first model can accommodate the blood that comes out during the childbirth process until the fourth stage. However, in a condition if the amniotic fluid comes out a lot or comes out during the second stage, the blood bag is not yet effective in distinguishing and separating between blood and amniotic fluid. Based on this reason, the researchers made revisions and manufactures of blood bags with different designs to separate blood and amniotic fluid. The blood bag has two parts; on the top, it uses a urine bag and the bottom uses a plastic that has a zipper to remove amniotic fluid and blood. In the condition of the mother giving birth whose membranes have not ruptured, the urine bag valve is left open so that the amniotic fluid can flow to the bottom, then in the process of assessing blood flow, the urine bag valve is closed again so that blood can be accommodated at the top and the amount can be assessed.

\section{Model 2}

Experiments carried out on model 2 mattress can be concluded that model 2 has an effectiveness percentage of $83.7 \%$ in which its qualification results are "very good" and the decision is "very feasible and does not need to be revised", but one of the midwives stated the hole in the mattress was too large coupled with the two separate surfaces allow it to loosen if the patient moves too hard. The large hole of this mattress, it is feared that if the patient gives birth to a small baby or the baby's umbilical cord is short, it can fall into the blood bag.

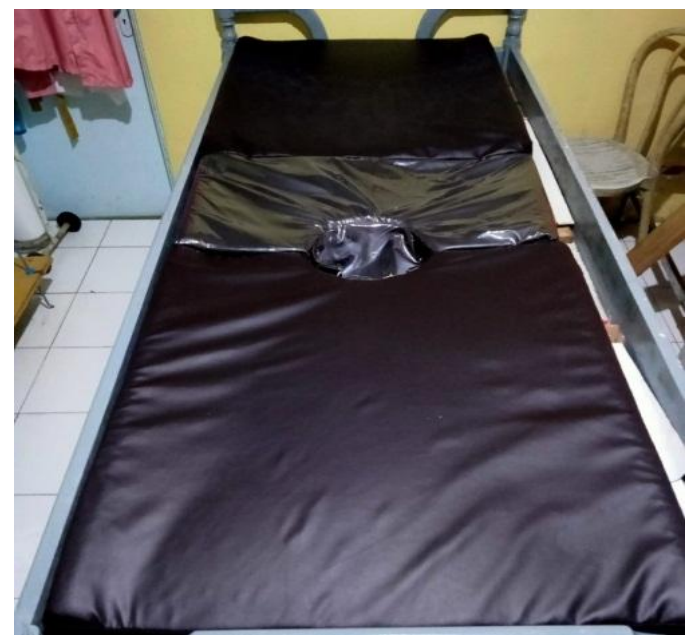

Model 2. Front View

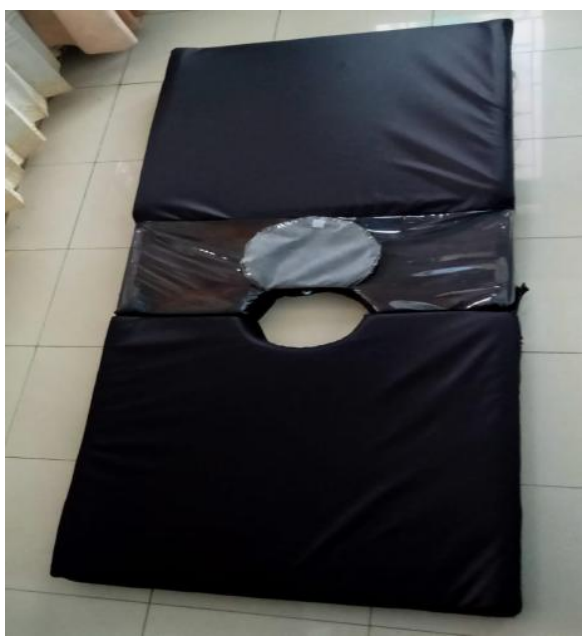

Model 2. Top View

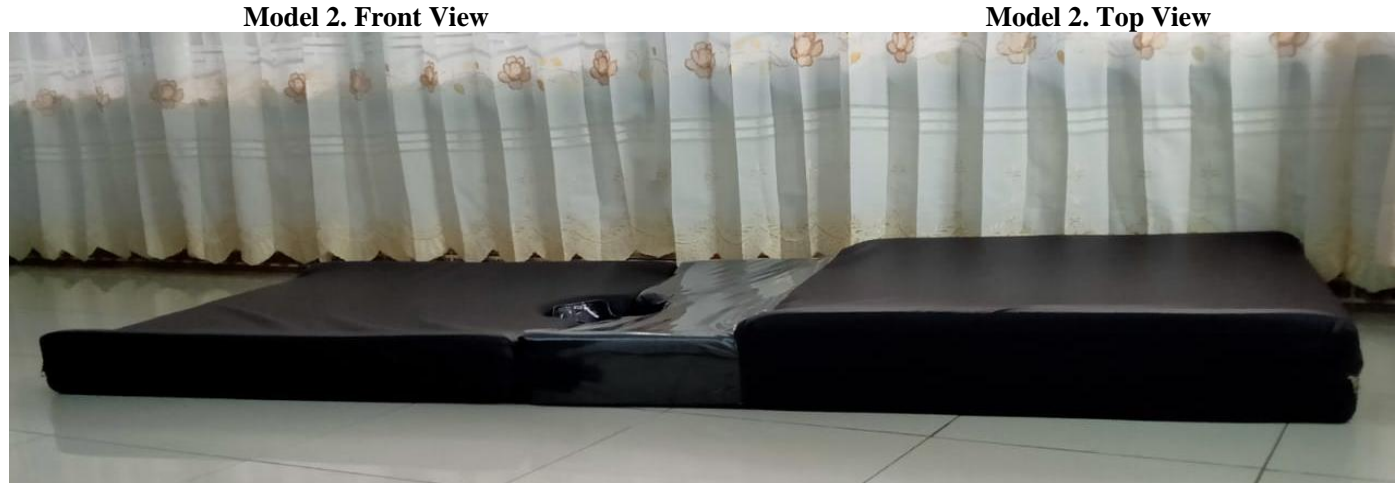

Model 2. Side View 


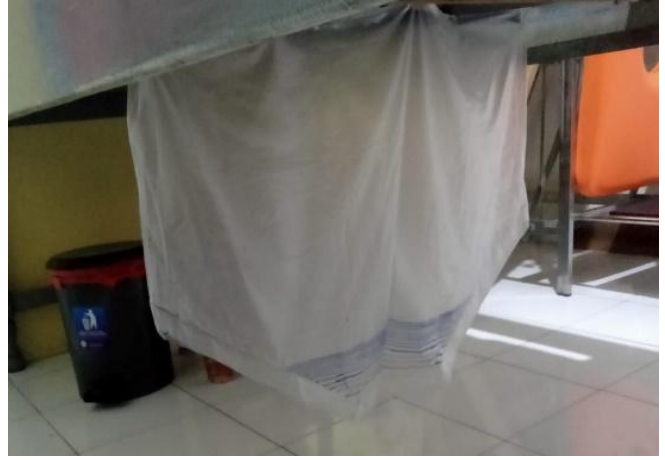

Blood bag that has not been filled with blood

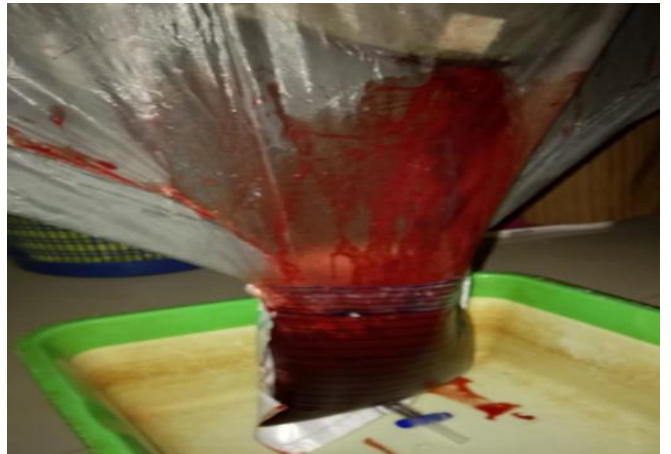

Blood bag that has been filled with blood of 1000cc with amniotic fluid looks separated at the top

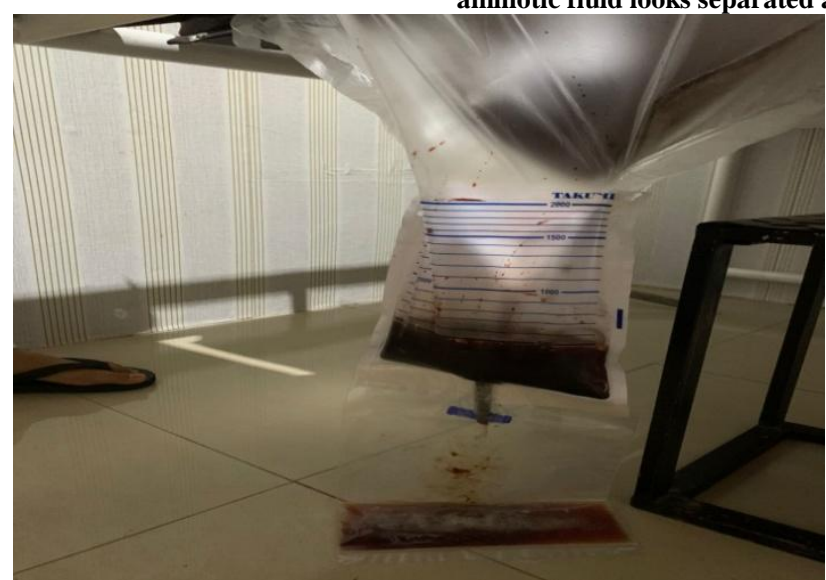

Revised blood bag with two different sections to separate blood and amniotic fluid. The urine bag is for measuring blood, the bottom is for the amniotic sac.

The blood bag in the second model can accommodate the blood that comes out during the delivery process until the 4th stage. The blood that comes out flows directly into the blood bag and does not spill onto other surfaces. Another advantage in certain situations (amniotic fluid comes out at the same time as the baby is born), this mattress can hold the amniotic fluid that comes out first so it does not go directly into the blood collection bag which can cause mixing of blood with amniotic fluid because there is a cover over the hole. However, there are also patients with a lot of amniotic fluid, so that the amniotic fluid flows into the blood bag and mixes with the delivery blood. Based on this reason, the researchers made revisions and manufactures of blood bags with different designs to separate blood and amniotic fluid. The blood bag has two parts; on the top, it uses a urine bag and the bottom uses a plastic that has a zipper to remove amniotic fluid and blood. In the condition of the mother giving birth whose membranes have not ruptured, the urine bag valve is left open so that the amniotic fluid can flow to the bottom, then in the process of assessing blood flow, the urine bag valve is closed again so that blood can be accommodated at the top and the amount can be assessed.

\section{Model 3}

Mattress model three is the most different mattress from model one and two. This model is made with a size resembling the blood reservoir that is commonly used today (underpad), then the blood reservoir is placed on both sides and its use is placed on the delivery bed. Experiments conducted on the model 3 mattress can be concluded that model 3 has an effectiveness percentage of $51.3 \%$ in which its qualification results are "enough" and the decision is "not feasible and needs to be revised". The surface of the model three mattress has a thickness that is less precise so that the blood that comes out during the delivery process does not directly flow into the blood bag on the right and left sides of the mattress. The birth attendant 
needs to put pressure on the right and left sides so that blood can flow into the urine bag as a delivery blood measuring bag.

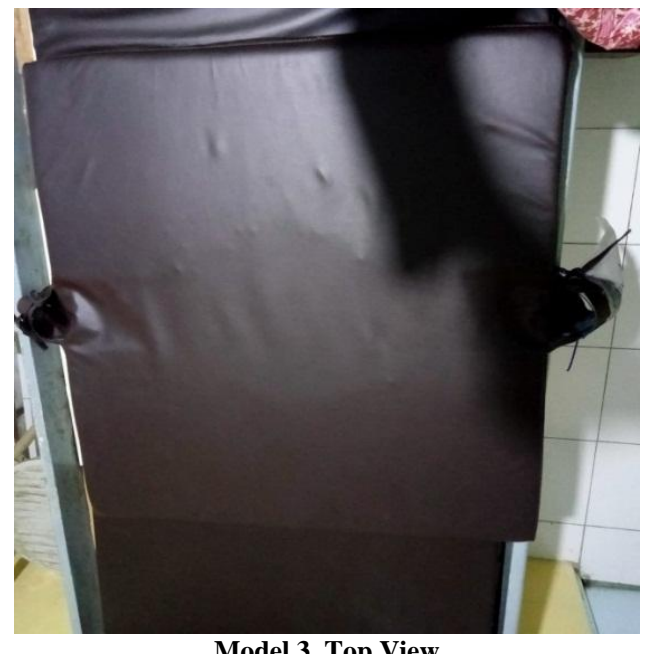

Model 3. Top View

To analyze the difference in product effectiveness, One Way Anova analysis was then carried out because the data in this study were normally distributed and homogeneous. Based on table 3, it can be seen that the $\mathrm{p}$ value $=0.000$, it can be concluded that the average assessment given by patients and midwives on the three mattress models has a significant difference. Then, the Pos Hoc follow-up test is carried out as shown in table 4. In the Post Hoc Turkey HSD test above, it can be concluded that there is no difference in the mean of patient assessment between model 1 and model 2 with $\mathrm{p}$ value $=0.239$. This means that the patient assesses that the two mattresses are equally effective both in terms of function and comfort in their use during labor. The case is different between model 1 and model 3 and model 2 and model 3, that is, there is a significant difference. Model 1 and model 3 have a $p$ value $=0.009$ with an average difference of 2,700 while model 2 and model 3 have a $p$ value $=0.000$ with an average difference of 4,100 .

In the Post Hoc Turkey HSD test above, it can be concluded that there is a significant difference in the average of the midwives' assessments on the three mattress models. This means that the midwife
Moreover, in patients who are overweight, the center of the mat gets steeper, so that blood collects under the patient's buttocks.

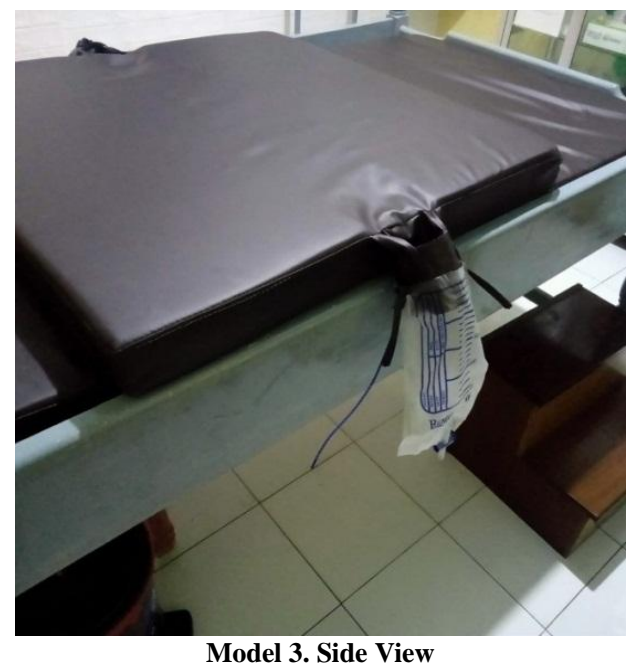

considers that the three mattresses have different effectiveness. Model 1 and model 2 have a $\mathrm{p}$ value $=0.000$ with an average difference of 5,800, model 1 and model 3 have a $\mathrm{p}$ value $=0.000$ with an average difference of 6,900, while model 2 and model 3 have a $\mathrm{p}$ value $=0.000$ with an average of 12,700. To assess the most effective mattress in this study, it can be seen in table 5 and it can be concluded that the most effective mattress according to the assessment of the midwife and patient is the number two mattress (2) with the highest average value among the other two mattresses.

Based on statistical tests, it can be concluded that the most effective in the assessment of midwives and patients is the Mattress model Two (2) because in terms of the comfort of using the patient and the mattress is effective in draining blood into the blood bag and can accommodate amniotic fluid first and the blood bag has two parts that separates the amniotic fluid in the lower pocket and the blood in the upper pocket. This is in line with the research of Fitriaturohmah et al (2019) which concluded that the use of a blood collection bag is more effective and more practical to use compared to the use of conventional tools (18). The effectiveness of a tool is 
considered good if it has the practicality and conveniences that exist in the instrument either in preparing, using, interpreting, obtaining results, or convenience in storing so that researchers do not provide inclusion criteria in the use of mattresses because the purpose of making mattresses is that it can be used by maternity mothers in any condition so that the amount of blood loss can be assessed immediately and becomes a diagnosis in the delivery process and the patient can be treated immediately in the event of postpartum hemorrhage.

This research is inseparable from all the obstacles; one of which is that the process of making blood bags is still manual and with available materials so that further research is expected to improve blood bags both in terms of materials and components so that blood assessment can be calculated accurately.

\section{CONCLUSION}

Based on statistical tests, it can be concluded that the most effective in measuring blood volume is the Model Two Mattress.

\section{Acknowledgement: None}

\section{Conflict of Interest: None}

\section{Source of Funding: None}

Ethical Approval: Approved

\section{REFERENCES}

1. WHO. Trends In Maternal Mortality. 2019; Available from: https://www.who.int/reproductivehealth/p ublications/maternal-mortality-20002017/en/

2. Dinas Kesehatan Kalimantan Barat. Profil Kesehatan Provinsi Kalimantan Barat Tahun 2018. 2019;

3. Herayono F, Basyir V. Perbedaan Jumlah Perdarahan Saat Persalinan Pada Ibu Primigravida Yang Melakukan Dan Tidak Melakukan Senam Hamil Selama Kehamilan Trimester III. :5.
4. WHO E. Maternal mortality: Levels and trends 2000 to 2017. 2019; Available from:

https://www.who.int/reproductivehealth/p ublications/maternal-mortality-20002017/en/

5. Kemenkes. Panduan Pelayanan Pasca Bagi Ibu dan Bayi Baru Lahir. 2019;

6. Say L, Chou D, Gemmill A, Tunçalp Ö, Moller A-B, Daniels J, et al. Global causes of maternal death: a WHO systematic analysis. Lancet Glob Health. 2014 Jun;2(6):e323-33.

7. Achadi EL. Kematian Maternal dan Neonatal di Indonesia. Rakernas 2019 Pp 1-47. 2019;

8. Schorn MN. Measurement of Blood Loss: Review of the Literature. J Midwifery Womens Health. 2010 Jan 2;55(1):20-7.

9. Budiman DM. Perdarahan Post Partum Dini e.c Retensio Plasenta. J Medula Unila. 2017;7:6-9.

10. K. D. Jayanti, H. B. N AW. Faktor Yang Memengaruhi Kematian Ibu (Studi Kasus Di Kota Surabaya). J Wiyata Penelit Sains Dan Kesehat. 2017;3(1):46-53.

11. S. Sumarni. Model sosio ekologi perilaku kesehatan dan pendekatan Continuum Of Care Untuk Menurunkan Angka Kematian Ibu. J Public Health. 2017;129-41.

12. Marmi. Asuhan Kebidanan Pada Persalinan. Yogyakarta: Pustaka Pelajar; 2012.

13. Cunningham et al. William Obstetric 23 Edition section 'Obstetrical Hemorrhage. 24th ed. New York: McGraw-Hill Education/Medical; 2014.

14. Al Kadri HMF, Al Anazi BK, Tamim HM. Visual estimation versus gravimetric measurement of postpartum blood loss: a prospective cohort study. Arch Gynecol Obstet. 2011 Jun;283(6):1207-13.

15. Diaz V, Abalos E, Carroli G. Methods for blood loss estimation after vaginal birth. Cochrane Pregnancy and Childbirth Group, editor. Cochrane Database Syst Rev [Internet]. 2018 Sep 13 [cited 2020 Oct 29]; Available from: http://doi.wiley.com/10.1002/14651858.C D010980.pub2

16. Panggayuh A, Jupriyono J. Perbedaan Estimasi Volume Perdarahan Antara 
Metode Tes Hemoglobin Dengan Metode Visual Estimasi Pada Ibu Postpartum. J Ilmu Kesehat. 1970 Jan 1;5(2):106.

17. Arikunto S. Manajemen Penelitian. Jakarta: Rineka Cipta; 2016.

18. Fitriaturohmah et al. Efektivitas Kantung Penampung Darah Dibandingkan Dengan Alat Penampung Darah Konvensional Dalam Upaya Penampungan Darah Pada
Persalinan. JSK, Volume 5 Nomor 2 Desember 59-65.2019

How to cite this article: Noftalina E, Purnamasari I, Wulandari FK et.al. The effectiveness of blood loss measuring mattress in maternity. International Journal of Research and Review. 2021; 8(10): 429-439. DOI: https://doi.org/10.52403/ijrr.20211058 